\title{
Pengaruh Etos Kerja Terhadap Kinerja Karyawan PT Indofarma Global Medika Cabang Palembang
}

\author{
Muhammad Deni \\ Universitas Sjakhyakirti Palembang \\ Email:muhammaddeni1775@gmail.com
}

\begin{abstract}
ABSTRAK
Penelitian ini bertujuan untuk menganalisis, mengetahui dan membuktikan pengaruh etos kerja terhadap kinerja karyawan di PT Indofarma Global Medika Cabang Palembang. Penelitian ini menggunakan analisis asosiatif yaitu penelitian yang berusaha mencari pengaruh ataupun hubungan antara satu atau lebih. Sampel yang digunakan dalam penelitian ini seluruh karyawan PT Indofarma Global Medika cabang Palembang yang berjumlah 24 orang. Adapun teknik pengumpulan data yang digunakan dalam penelitian ini yaitu dokumentasi dari kuesioner yang di berikan kepada seluruh karyawan PT Indofarma Global Medika cabang Palembang (populasi). Metode analisis yang digunakan adalah metode analisis dengan menggunakan jalur program IBM SPSS Statistics for Windows Version 24.

Berdasarkan hasil penelitian ini disimpulkan bahwa terdapat pengaruh etos kerja terhadap kinerja karyawan PT Indofarma Global Medika cabang Palembang. Adapun saran yang dapat penulis berikan adalah hedaknya pihak perusahaan memberikan fonsasi yang kuat, memberikan penghargaan terhadap karyawan yang berprestasi dan terus memberikan coaching clinic kepada karyawannya agar para karyawan tetap percaya diri dalam bekerja, terbebas dari rasa jenuh dalam bekerja dan dapat menyelesaikan target yang telah diberikan perusahaan.

Kata kunci : Etos Kerja, Kinerja Karyawan.
\end{abstract}

\section{PENDAHULUAN}

\section{LATAR BELAKANG}

Pada masa pandemi seperti sekarang sudah bukan rahasia umum lagi bahwa perusahaan lintas sektor melakukan upaya-upaya adaptasi bisnis agar tidak kehilangan pasar di masa pandemi corona (COVID-19). Hal yang sama dilakukan perusahaan-perusahaan farmasi maupun alat kesehatan (alkes) yang selama ini di stigmakan tidak banyak terdampak pandemi. Salah satu adaptasi yang dilakukan di antaranya komposisi penjualan produk, kegiatan pemasaran, penjualan, dan yang sangat penting adalah dari sektor sumber daya manusianya dengan kondisi 
normal baru di masa pandemi, karena manajemen sumber daya manusia merupakan hal yang sangat penting dalam sebuah perusahaan untuk menjalankan visi dan misi perusahaan tersebut.

Sumber daya manusia merupakan suatu masalah yang paling pentingdalam perusahaan, karena melalui sumber daya manusia lah yang menyebabkan sumber daya yang lain dalam perusahaan dapat menciptakan efesiensi dan efektifitas perusahaan selain sumber daya manusia, dan dari sumber daya manusia itu pula perusahaan bisa mengendalikan serta membentuk sikap serta perilaku (etos kerja) dari seorang karyawannya.

Etos kerja adalah sikap yang muncul atas kehendak dan kesadaran diri yang di dasari oleh sistem orientasi budaya terhadap kerja (sukardewi, 2013:3). Sikap ini tidak hanya di miliki individu, tetapi juga oleh kelompok bahkan masyarakat. Etos di bentuk oleh berbagai kebiasaan, pengaruh budaya, serta sistem nilai yang di yakininya (Tasmara, 2002:15). Menurut Simano (2011:26), etos kerja adalah seperangkat perilakukan positif yang berakar pada keyakinan fundamental yang di sertai komitmen total pada paragdigmakerja yang integral. Etos kerja juga sangat penting untuk mendorong kinerja karyawan dalam suatu perusahaan untuk melakukan serangkaian kegiatan yang mengarah tercapainya tujuan tertentu. Jika seseorang mempunyai Etos kerja yang baik maka akan berupaya sekuat tenaga untuk mencapai tujuannya sebagaimana hal itu nantinya berakhir menjadi kepuasan atau kebutuhan orang tersebut. Dengan adanya etos kerja yang baik maka kinerja karyawan juga akan baik.

Kinerja karyawan adalah hasil kerja yang dimiliki oleh karyawan dengan cara bertanggung jawab dalam pekerjan yang diberikan kepadanya. Menurut Anwar Prabu Mangkunegara (2000) kinerja dalah hasil kerja sesuai kualitas dan kuantitas yang di capai oleh seseorang dalam melaksanakan tugasnya sesuai tanggung jawab yang di berikan kepadanya. Kinerja karyawan merupakan hal penting dalam suatu perusahaan, karena dengan memiliki kinerja karyawan yang baik maka kualitas suatu perusahaan akan semakin baik. Kinerja karyawan dapat dinilai dengan cara melakukan penilaian kinerja karyawan secara berkala. Penilaian kinerja dilakukan secara efektif untuk mengarahkan perilaku karyawan dalam rangka menghasilkan jasa dengan kualitas yang tinggi.Selain itu, penilaian 
kinerja juga dilakukan untuk memotivasi karyawan melakukan tugas-tugasnya dan mewujudkan tujuan perusahaan, manfaat dari penilaian kinerja digunakan untuk perbaikan prestasi kerja, penyesuaian kompensasi, kebutuhan pengembangan, serta melihat penyimpangan maupun kesalahan dalam pekerjaan.

Menurut Nur Azizah, syamsul Alam, dan Muhammad Basri pada penelitiannya di tahun 2019 dengan judul pengaruh etos kerja terhadap kinerja pegawai pada dinas koperasi, usaha mikro, kecil dan menengah provinsi Sulawesi utara, "Etos kerja pegawai berpengaruh positif terhadap kinerja pegawai artinya makin tinggi etos kerja pegawai maka makin tinggi pula kinerja pegawai. Hal ini dikarenakan pegawai yang mempunyai etos kerja yang tinggi pada umumnya dapat menunjukkan pencapaian atau kinerja yang lebih tinggi dibandingkan dengan pegawai yang mempunyai etos kerja yang rendah".

PT Indofarma Global Medika Cabang Palembang merupakan salah satu perusahaan yang bergerak dalam bidang perdagangan dan distribusi obat, alat Kesehatan, diagnostic, dan hospitas furniture serta kerjasama operasi laboratorium rumah sakit terpadu di kota Palembang. Produknya juga bermacammacam yaitu OGB (obat generik berlogo biru), Herbal Medicine, Obat Ethical, dan alat-alat kesehatan. PT indofarma global medika juga meupakan salah satu anak perusahaan BUMN yaitu PT indofarma (persero) Tbk yang bergerang dalam bidang produksi obat-obat generik, dengan demikian Sebagian besar produk PT Indofarma Tbk di distribusikan memalui PT Indofarma global medika.

PT Indofarma global medika melakukan otomatisasi pengawasan terhadap tenaga penjual yang ada dilapangan melalui penerapan sales forceautomation berbasis cloud yang mencakup pembuatan, pengiriman dan penyelesaian pekerjaan lapangan dengan system penyimpanan yaitu sistem FEFO (First Expired First Out) jadi barang-barang yang masa berlakunya lebih pendek itu yag pertama sekali di distribusikan. PT Indofarma global medika memiliki karyawan sekitar 24 orang.Berikut data karyawan dapat di lihat dari tabel di bawah ini:

Tabel 1

Karyawan PT Indofarma Global Medika cabang Palembang 


\begin{tabular}{|l|l|l|l|}
\hline No & Keterangan Karyawan & Jumlah & Status Kepegawaian \\
\hline 1 & Kepala cabang & 1 orang & Karyawan Tetap \\
\hline 2 & Tenaga support & 8 orang & Karyawan Tetap \\
\hline 3 & Tenaga support & 4 orang & Karyawan PKWT \\
\hline 4 & Tenaga lapangan & 6 orang & Karyawan Tetap \\
\hline 5 & Tenaga lapangan & 5 orang & Karyawan PKWT \\
\hline \multicolumn{3}{|c|}{ Total } & 24 Orang \\
\hline
\end{tabular}

\section{Sumber: PT Indofarma Global Medika Cabang Palembang}

Sehubungan dengan data di atas dapat di katakana bahwa jumlah karyawan cukup untuk menjalankan visi dan misi perusahaan dengan jam kerja 45 jam 1 minggu yang mungkin tidak jauh berbeda dengan beberapa perusahaan yang bergerak di bidang yang sama dan sudah menunjukan sebgian potensi etos kerja yang baik dalam pekerjaan. Hal tersebut dapat di lihat dari masih tingginya semangat kerja yang di buktikan dengan minimnya absensi di setiap bulannya,

Namun di masa pandemi seperti sekarang banyaknya peraturan pemerintah terkait pembatasan untuk memutus mata rantai covid-19 yang masih menyebar luas di Indonesia bahkan di seluruh dunia sedikit membuat beberapa karyawan sedikit belum bisa beradaptasi dengan beberapa aturan yang harus di taati selama pandemi dan rasa takut yang terus tetap menghantui akan terindikasi virus covid19 karna mesti harus tetap melakukan kunjungan ke apotek-apotek, rumah sakit, dinas Kesehatan, dan laian-lain yang menjadi tujuan pasar perusahaan.Oleh karena itu beberapa karyawan sedikit kurang percaya diri dalam melakukan tugas untuk melakukan kunjungan dan menjalin komunikasi dengan satuan kerja untuk melakukan penawaran produk sehingga hasil yang di dapat kurang maksimal, mereka juga mengalami kejenuhan karena banyak kegiatan sekarang yang di batasi untuk mematuhi protokol kesehatan yang telah di terapkan seperti tidak bisanya bertemu langsung dengan satuan kerja untuk melakukan penawaran produk dan juga tidak bisa bertatap muka saat melakukan meeting koordinasi di 
setiap kesempatannya. Dengan keadaan ini juga yang membuat beberapa karyawan menjadi sedikit kehilangan rasa semangat kerja karena target penjualan yang juga menjadi salah satu tolak ukur kinerja karyawan yang telah di tetapkan tidak tercapai.

\section{KAJIAN PUSTAKA}

\section{Etos Kerja}

Etos kerja adalah sikap yang muncul atas kehendak dan kesadaran sendiri yang didasari oleh sistem orientasi nilai budaya terhadap kerja (Sukardewi, 2013:3).Etos berasal dari bahasa Yunani, yaitu ethos yang artinya sikap, kepribadian, watak, karakter, serta keyakinan atas sesuatu.Sikap ini tidak saja dimiliki oleh individu, tetapi juga oleh kelompok bahkan masyarakat.Etos dibentuk oleh berbagai kebiasaan, pengaruh budaya, serta sistem nilai yang diyakininya (Tasmara, 2002:15)..

\section{Kinerja}

Kinerja karyawan adalah hal yang memiliki sifat individu, karena setiap karyawan memiliki tingkat kualifikasi yang berbeda dan kinerja yang berbeda dalam kaitannya dengan tugasnya. Manajemen dapat mengukur kinerja karyawan berdasarkan kinerja masing-masing karyawan tersebut. Kinerja adalah aksi, bukan peristiwa. Yaitu aksi kinerja itu sendiri terdiri dari banyak komponen dan bukan hasil langsung.Pada dasarnya, kinerja adalah sesuatu yang individual, karena setiap karyawan memiliki kemampuan berbeda untuk melakukan pekerjaannya. Kinerja tergantung pada kombinasi keterampilan, upaya, dan peluang yang diperoleh. Ini berarti bahwa kinerja adalah hasil dari pekerjaan karyawan selama periode tertentu dan fokusnya adalah pada pekerjaan karyawan dalam periode tertentu. Kinerja tersebut berasal dari kata kinerja kerja atau kinerja aktual yang berarti bahwa seseorang telah melakukan kinerja kerja atau kinerja aktual. Kinerja berarti pekerjaan kualitatif dan kuantitatif yang dilakukan seorang karyawan ketika ia melakukan tugasnya sesuai dengan tanggung jawab yang diberikan kepadanya.

\section{METODOLOGI PENELITIAN}

\section{Desain Penelitian}


Desain penelitian yang dilakukan dalam penelitian ini adalah Penelitian ini dapat digolongkan ke dalam jenis penelitian asosiatif, Yakni penelitian ini untuk mengetahui Pengaruh Etos Kerja Terhadap Kinerja Karyawan PT Idoforma Global Medika Cabang Palembang.

\section{Lokasi Penelitian}

Lokasi penelitian dilakukan melalui Karyawan PT Idoforma Global Medika Cabang Palembang. Penetapan Unit analisis ini didasarkan pada Etos Kinerja Karyawan PT Idoforma Global Medika Cabang Palembang.

\section{Metode Pengumpulan dan Analisa Data}

Teknik pengambilan data dalam penelitian ini adalah data primer dan data sekunder, yaitu dengan cara mengadakan teknik survey, observasi dan dengan dokumentasi. Teknik analisa data tersebut meliputi:

(1) Uji Validitas Intrumen

Uji validitas menunjukan ukuran yang benar-benar mengukur apa yang akan diukur. Semakin tinggi validitas suatu instrumen, maka instrumen tersebut semakin mengenai pada sasarannya, atau semakin menunjukan apayang seharusnya di ukur. Suatu instrumen dapat dikatakan mempunyai validitas tinggi apabila instrumen tersebut menjalankan fungsi ukurnya.

Salah satu cara untuk menghitung validitas suatu innstrumen yaitu dengan melihat daya pembeda item (item discriminality). Daya pembeda item adalah metode yang paling tepat digunakan untuk setiap jenis test. Daya pembeda item dalam penelitian ini dilakukan dengan cara "korelasi item-total". Korelasi itemtotal yaitu konsistensi antara skor item dengan skor secara keseluruhan yang dapat dilihat dari besarnya koefisien korelasi antara setiap item dengan skor keseluruhan.

Pengukuran validitas instrumen menggunakan bantuan program IBM SPSS Statistic for windows version 24 dengan metode Product momen pearson.

$$
\mathrm{r}_{x y}=\frac{\sum x y}{\sqrt{\left(\sum x^{2}\right)\left(\Sigma y^{2}\right.}}
$$

Keterangan

$r_{x y} \quad:$ korelasi antara variabel $\mathrm{X}$ dan $\mathrm{Y}$ 
$\Sigma_{x} \quad$ : jumlah skor tiap item dari seluruh responden uji coba

$\Sigma_{y} \quad$ : jumlah skor total (seluruh item) dari seluruh responden uji coba

(2) Uji Reabilitas Intrumen

Relabilitas artinya adalah tingkat keterpercayaan hasil suatu pengukuran. Pengukuran yang memiliki reliabilitas tinggi, yaitu pengukuran yang mampu memberikan hasil ukur yang terpercaya (reliable). Reliabilitas merupakan salah satu ciri atau karakter utama instrumen pengukur yang baik. Reliabilitas di sebut juga sebagai keterpecayaan, keterandalan, konsistensi, kestabilan dan sebagainya. Namun ide pokok dalam konsep reliabilitas adalah sejauh mana hasil suatu pengukuran dapat di percaya, artinya sejauh mana skor hasil pengukuran terbebas dari kekeliruan pengukuran (measurement error). Menurut sugiyono (2011) suatu instrumen di katakan reliable adalah jika nilai koefisien reliabilitasnya lebih besar dari 0,6. Uji reliabilitas instrumen dalam penelitian ini akan digunakan koefisien Cronbach's Alpha dari program IBM SPSS Statistics for windows version 24.

(3) Uji Regresi Linear Sederhana

Metode analisis data dengan uji statistik regresi linier sederhana yang digunakan dalam penelitian ini merupakan peralatan statistik untuk melihat hubungan dan pengaruh antara variabel bebas $(\mathrm{X})$ etos kerja serta variasbel terikat (Y) yaitu kinerja karayawan.

Model persamaan regresi linier sederhana yang terbentuk adalah:

Keterangan

$$
\mathbf{Y}=\mathbf{a}+\mathbf{b} \mathbf{X}
$$

Y : kinerja karyawan atau subjek atau nilai dalam variabel dependen yang diprediksikan

a : harga $\mathrm{Y}$ bila $\mathrm{X}=0$ (harga konstan)

b : angka arah atau koefisien regresi, yang menunjukan angka di dasarkan pada variabel independen. Bila b (+) maka naik dan bila (-) maka terjadi penurunan

$\mathrm{X}$ : subjek pada variabel independen yang mempunyai nilai tertentu

e : variabel lain yang tidak diteliti

(4) Koefisien Korelasi (r) 
Untuk mengukur keeratan hubungan antara variabel independen dan variabel dependen dapat di lihat dari nilai $\mathrm{r}$ yang mempunyai range antara -1 hingga +1 bila nilai $\mathrm{r}$ semakin mendekati +1 atau -1 , berarti semakin erat hubungan positif dan negatif antara variabel independen dan variabel dependen. Sedangkan bila nilai $\mathrm{r}$ semakin mendekati 0 (nol), berarti terdapat hubungan yang semakin lemah. Nilai r yang paling besar menunjukan bahwa variabel independen yang bersangkutan paling erat hubungannnya dengan variabel dependen. Oleh karena itu merupakan variabel independen $\mathrm{X}$ yang paling dominan dalam menjelaskan variasi dalam variabel dependen $\mathrm{Y}$.

(5) Uji Hipotesis Penelitian (Uji t)

Untuk melihat pengaruh dari masing-masing variabel bebas terhadap variabel terikat dapat di jelaskan dengan menggunakan uji statistik. Adapun kriteria pengujiannya adalah (Ghozali, 2011):

$\mathrm{H}_{o}$ diterima artinya tidak berpengaruh signifikan, jika sig $\mathrm{t}(p$-value) $>0,05$ dan $\mathrm{t}_{\text {hitung }}<\mathrm{t}_{\text {tabel }}$.

$\mathrm{H}_{\mathrm{a}}$ diterima artinya berpengaruh signifikan, jika sig $\mathrm{t}(p$-value $)>0,05$ dan $\mathrm{t}_{\text {hitung }}<\mathrm{t}_{\text {tabel }}$.

$\mathrm{H}_{\circ} \quad$ : variabel bebas tidak berpengaruh signifikan terhadap variabel terikat.

$\mathrm{H}_{\mathrm{a}} \quad$ : variabel bebas berpengaruh signifikan terhadap variabel terikat.

Untuk menentukan harga $t_{\text {tabel }}$, taraf nyata digunakan sebesar $5 \%$ dengan derajat kebebasan df (n-k-1) dimana merupakan jumlah variabel bebas. Sedangkan harga $t_{\text {hitung }}$ dapat dilihat dari nilai $\mathrm{t}$ pada tabel coefficients hasil analisis regresi linier sederhana program IBM SPSS statistics for windows version 24.

\section{HASIL DAN PEMBAHASAN}

\section{Hasil Penelitian}

Pada penelitian ini teknik analisis data yang digunakan adalah regresi linear sederhana. Hasil analisis regresi linear berganda yang telah dilakukan 
dengan menggunakan bantuan program Statistical Product and Service Solution (SPSS versi 24) adalah sebagai berikut :

a. Uji Validitas

Tabel 2

Rangkuman hasil uji validitas instrumen kuesioner variabel independen $(\mathrm{X})$ dan variabel dependen $(Y)$

\begin{tabular}{|c|c|c|c|c|}
\hline Variabel Idependen (Y) & No. Butir & $r_{\text {hitnung }}$ & $r_{\text {tabel }}$ & Interpretasi \\
\hline \multirow{2}{*}{ Kerja Keras } & 1 & $0,528 * *$ & \multirow{10}{*}{0,413} & Valid \\
\hline & 2 & $0,426^{*}$ & & Valid \\
\hline \multirow{3}{*}{ Disiplin } & 3 & $0,426^{*}$ & & Valid \\
\hline & 4 & $0,413^{*}$ & & Valid \\
\hline & 5 & $0,528^{* *}$ & & Valid \\
\hline Jujur & 6 & $00,486^{*}$ & & Valid \\
\hline \multirow{2}{*}{ Tanggung Jawab } & 7 & $0,427 *$ & & Valid \\
\hline & 8 & $0,528^{* *}$ & & Valid \\
\hline Rajin & 9 & $0,413^{*}$ & & Valid \\
\hline Tekun & 10 & $0,422^{*}$ & & Valid \\
\hline Variabel Dependen (X) & No. Butir & $\boldsymbol{r}_{\text {hitnung }}$ & $r_{\text {tabel }}$ & Interpretasi \\
\hline Kualitas & 11 & $0,528^{* *}$ & \multirow{6}{*}{0,413} & Valid \\
\hline Kuantitas & 12 & $0,440^{*}$ & & Valid \\
\hline Aktualitas Dan Ketepatan Waktu & 13 & $0,427^{*}$ & & Valid \\
\hline \multirow{2}{*}{ Efektivitas } & 14 & $0,528 * *$ & & Valid \\
\hline & 15 & $0,427^{*}$ & & Valid \\
\hline Kemandirian Dan Otonomi & 16 & $0,618^{* * *}$ & & Valid \\
\hline
\end{tabular}

Sumber: hasil pengolahan data SPSS, 2021.

Pada tabel 2 didapat bahwa nilai $r_{\text {hitnung }}$ untuk seluruh butir kuesioner sebagai instrumen alat ukur variabel penelitian terdiri dari 10 butir pernyataan untuk variabel bebas (X) etos kerja karyawan dan 6 butir peryantaan untuk variabel terikat (Y) kinerja karyawan PT Indofarma Global Medika Cabang 
Palembang adalah lebih besar dari nilai $r_{\text {tabel }}$ 0,413. Dengan demikian, maka hasil ini menunjukan pada taraf signifikan 5\%, seluruh butir instrumen kuesioner dinyatakan valid dan memenuhi syarat sebagai alat ukur untuk dilakukan analisi selanjutnya.

Tabel 3

\section{Rangkuman hasil uji reliabilitas instrumen kuesioner variabel independen (X) dan variabel dependen (Y)}

\begin{tabular}{|c|c|c|}
\hline \multicolumn{3}{|c|}{ Variabel X } \\
\hline \multicolumn{3}{|c|}{ Reliability Statistics } \\
$\begin{array}{c}\text { Cronbach's } \\
\text { Alpha }\end{array}$ & $\begin{array}{c}\text { Alpha Based } \\
\text { on } \\
\text { Standardized } \\
\text { Items }\end{array}$ & N of Items \\
\hline 0,733 & 0,555 & 10 \\
\hline
\end{tabular}

Variabel Y

\begin{tabular}{|c|c|c|c|}
\hline \multicolumn{3}{|c|}{ Reliability Statistics } \\
\hline $\begin{array}{c}\text { Cronbach's } \\
\text { Alpha }\end{array}$ & $\begin{array}{c}\text { Cronbach's } \\
\text { on Based } \\
\text { ondandized } \\
\text { Items }\end{array}$ & N of Items & \\
\hline 0,811 & 0,412 & 6 & \\
\hline
\end{tabular}

Sumber: hasil pengolahan data SPSS, 2021.

Dapat dilihat pada tabel 3 nilai koefisien reliabilitas Cronbach Alpha untuk semua variabel lebih besar dari 0,6. Dengan demikian, hasil ini menunjukan bahwan instrumen koesioner yang digunakan sebagai alat ukur variabel penelitian dinyatakan memenuhi syarat dan dapat diandalkan. 
Berdasarkan data hasil uji statistik regresi linier sederhana didapat nilai untuk mengestimasi model persamaan regresi untuk variabel terikat (Y) kinerja karyawan, yaitu:

$$
Y=1,281+1,528
$$

Data pada model persamaan regresi diatas nilai yang didapat menunjukan bahwa:

1. Nilai kosntanta sebesar 1,281 , hal ini dapat diartikan bahwa nilai kinerja karyawan adalah sebesar 1,281 (poin) dengan asumsi etos kerja yang terdiri dari kerja keras; disiplin; jujur; tanggung jawab; rajin; dan tekun; adalah tidak mengalami perubahan (konstanta).

2. Niali koefisien regresi variabel etos kerja (X) bertanda positif sebesar 1,528 dengan tingkat probabilitas ( $p$ value) $0,005(<0,05)$. Berdasarkan nilai ini dapat diasumsikan bahwa setiap peningkatan nilai etos kerja sebesar 1 poin maka nilai kinerja karyawan akan meningkat sebesar 1,528 poin lebih tinggi dari nilai sebelumnya.

Hasil tersebut dapat dilihat pada tabel 4 berikut:

Tabel 4

Hasil Uji Regresi Linier Sederhana

\begin{tabular}{|c|c|c|c|c|c|c|}
\hline \multicolumn{6}{|c|}{ Coefficients $^{\text {a }}$} \\
\hline \multicolumn{2}{|c|}{ Model } & Unstandardized Coefficients & $\begin{array}{c}\text { Standardized } \\
\text { Coefficients }\end{array}$ & t Sig. \\
\hline \multirow{2}{*}{} & & B & $\begin{array}{c}\text { Std. } \\
\text { Error }\end{array}$ & Beta & & \\
\hline 1 & (Constant) & 1,281 & 6,800 & & 2,864 & 0,003 \\
\hline & etos kerja & 1,528 & 0,670 &, $839 \mathrm{~b}$ & 4,416 & 0,000 \\
\hline
\end{tabular}

Sumber: hasil pengolahan data SPSS, 2021 


\section{Tabel 6}

\section{Hasil Uji Realibilitas}

\begin{tabular}{|c|c|c|}
\multicolumn{2}{|c|}{ Variabel X } \\
\hline \multicolumn{3}{|c|}{ Reliability Statistics } \\
$\begin{array}{c}\text { Cronbach's } \\
\text { Alpha }\end{array}$ & $\begin{array}{c}\text { Cronbach's } \\
\text { Alpha Based } \\
\text { on } \\
\text { Standardized } \\
\text { Items }\end{array}$ & N of Items \\
\hline 0,733 & 0,555 & 10 \\
\hline
\end{tabular}

Sumber: hasil pengolahan data SPSS, 2021.

Variabel Y

\begin{tabular}{|c|c|c|}
\hline \multicolumn{3}{|c|}{ Reliability Statistics } \\
\hline $\begin{array}{c}\text { Cronbach's } \\
\text { Alpha }\end{array}$ & $\begin{array}{c}\text { Cronbach's } \\
\text { Alpha Based } \\
\text { on } \\
\text { Standardized } \\
\text { Items }\end{array}$ & N of Items \\
\hline 0,811 & 0,412 & 6 \\
\hline
\end{tabular}

Sumber: hasil pengolahan data SPSS, 2021.

Hasil uji koefisien korelasi (R) didapat nilai Crownbach's Alpha variabel etos kerja karyawan $(\mathrm{X})$ sebesar 0,733 dengan $N$ of item ( jumlah pernyataan yang valid) sebesar 10 dan variabel kinerja karyawan (Y) sebesar 0,811 dengan $N$ of ietm (jumlah pernyataan yang valid) sebesar 6 kesemua variabel dinyatakan reliabel karna nilai Crownbach's Alpha > 0,6 maka dapat disimpulkan bahwa butir-butir instrumen penelitian tersebut reliabel

Tabel 7 


\section{Hasil Uji Koefisien Determinasi}

\begin{tabular}{|c|c|c|c|c|}
\hline \multicolumn{5}{|c|}{ Model Summary $^{\mathbf{b}}$} \\
\hline Model & $\mathrm{R}$ & R Square & Adjusted R Square & Std. Error of the Estimate \\
\hline & & & & 1,914 \\
\hline 1 &, $839^{\mathrm{b}}$ & 0,696 & 0,672 & \\
\hline
\end{tabular}

Sumber: hasil pengolahan data SPSS, 2021.

Dari tabel diatas diketahui nilai koefisien determinasi atau $R$ Square sebesar 0,696 atau 69,6\%. Variabel etos kerja (X) dapat dijelaskan atau mempengaruhi variabel kinerja karyawan (Y) PT Indofarma Global Medika Cabang Palembang sedangkan sisanya sebesar $30,4 \%$ berpengaruh dengan faktor lain yang tidak dibahas didalam penelitian seperti strategi, promosi, loyalitas karyawan dan faktor-faktor lain-lainnya.

Tabel 8

Uji Hipotesis (Uji t)

\begin{tabular}{|c|c|c|c|c|c|c|}
\hline \multicolumn{7}{|c|}{ Coefficients $^{\text {a }}$} \\
\hline Model & & $\begin{array}{c}\text { Unstandardized } \\
\text { Coefficients }\end{array}$ & & $\begin{array}{c}\text { Standardized } \\
\text { Coefficients }\end{array}$ & t Sig. \\
\hline & & B & $\begin{array}{c}\text { Std. } \\
\text { Error }\end{array}$ & Beta & & \\
\hline 1 & (Constant) & 1,281 & 6,800 & & 2,864 & 0,003 \\
\hline & etos kerja & 1,528 & 0,670 &, $839^{\mathrm{b}}$ & 4,416 & 0,000 \\
\hline \multicolumn{7}{|c|}{ a. Dependent Variable: kinerja karyawan } \\
\hline
\end{tabular}

Sumber : hasil perhitungan SPSS Versi 25 Tahun 2021

Pengujian hipotesi yang diajukan dalam penelitian ini menggunakan uji satistik $\mathrm{t}$ analisis regresi linier sederhana yang bertujuan untuk mengetahui tingkat keberartian pengaruh variabel bebas $(\mathrm{X})$ etos kerja terhadap variabel terikat (Y) kinerja karyawan PT Indofarma Global Medika Cabang Palembang. 
$\mathbf{t}_{\text {tabel }}=\mathbf{2 . 0 6 8 7}(\mathbf{d f}=\mathbf{n}-\mathbf{k}=\mathbf{2 4}-\mathbf{1}=\mathbf{2 3})$ ditaraf signifikan 0.05 .

Berdasarkan data hasil uji statistik t pada tabel diatas, diperoleh nilai sig $\mathrm{t}$ variabel etos kerja $(\mathrm{X})$ sebesar $0,000<\alpha=0,05$ dan $t_{\text {hitung }}>\mathrm{t}_{\text {tabel }}(4.4160>$ 2.0687), maka dapat dinyatakan bahwa $\mathrm{H}_{\mathrm{a}}$ diterima dan $\mathrm{H}_{\mathrm{o}}$ ditolak. Dengan demikian dapat dibuktikan bahwa hipotesis $\mathrm{H}_{\mathrm{a}}$ yang dinyatakan dengan terdapat pengaruh etos kerja terhadap kinerja karyawan PT Indofarma Global Medika Cabang Palembang diterima.

\section{Pembahasan}

\section{(1)Pengaruh Etos Kerja Terhadap Kinerja Pegawai}

Penelitian ini dilakuakn untuk mengetahui pengaruh etos kerja terhadap kinerja karyawan PT Indofarma Global Medika cabang Palembang. Dalam penelitian ini banyak sampel yang diambil ada 24 orang responden yang di berikan angket atau kuesioner. Dimana kuesioner tersebut berisi tentang = variabel yaitu etos kerja dan kinerja karyawan. Angket atau kuesioner yang diberikan berisi 10 pernyataan tentang etos kerja karyawan dan 6 pernyataan tentang kinerja karyawan. Pernyataan-pernyataan yang dibuat berdasarkan indikator dari masingmasing variabel.

Hasil rekap jawaban responden pada variabel bebas (X) etos kerja yang terdiri dari dimensi kerja keras; dimensi disiplin; dimensi jujur; dimensi tanggung jawab; dimensi rajin; dan dimensi tekun, didapat skor 4,00 ( kategori tinggi/baik) dengan persentase tingkat pelaksanaan variabel sebesar $80,00 \%$ dari skor maksimal. Yang mana dilihat dari skor rataan capaian dari masing-masing dimensi variabel bebas $(\mathrm{X})$ yang terdiri dari dimensi kerja keras yaitu sebesar 3,92 dengan tingkat persentase pelaksanaan sebesar 78,33\% (tinggi/baik); dimensi disiplin yaitu sebesar 3,93 dengan tingkat persentase pelaksanaan sebesar 78,91\% (tinggi/baik); dimensi jujur yaitu sebesar 3,92 dengan tingkat persentase pelaksanaan sebesar 78,33\% (tinggi/baik); dimensi tanggung jawab yaitu sebesar 4,17 dengan tingkat persentase pelaksanaan sebesar 83,33\% (tinggi/baik); dimensi rajin yaitu sebesar 3,96 dengan tingkat persentase pelaksanaan sebesar 79,17\% (tinggi/baik); dan dimensi tekun yaitu sebesar 4,13 dengan tingkat persentase pelaksanaan sebesar $82,50 \%$ (tinggi/baik). Dan pada variabel terikat (Y) kinerja 
karyawan yang terdiri dari dimesi kualitas kerja; dimensi kuantitas kerja; dimensi aktualitas dan ketepatan waktu; dimensi efektivitas; dan dimensi kemandirian dan otonomi, didapat bahwa juga berada pada kategori tinggi/baik. Skor capaian pelaksanaan variabel kinerja karyawan (Y) secara umum didapat skor sebesar 3,91 (kategori tinggi/baik) dengan persentase tingkat pelaksanaan variabel sebesar $78,19 \%$ dari skor maksimal. Hal tersebut ditinjau dari hasil skor capaian pada masing-masing dimensi variabel $\mathrm{Y}$ yang terdiri dari dimensi kualitas kerja yaitu sebesar 3,83 dengan tingkat persentase pelaksanaan sebesar 76,67\% (tinggi/baik); dimensi kuantitas kerja yaitu sebesar 4,08 dengan tingkat persentase pelaksanaan sebesar 81,67\% (tinggi/baik); dimensi aktualitas dan ketepatan waktu yaitu sebesar 3,96 dengan tingkat persentase pelaksanaan sebesar 79,17\% (tinggi/baik); dimensi efektivitas kerja yaitu sebesar 3,83 dengan tingkat persentase pelaksanaan sebesar 76,67\% (tinggi/baik); dan dimensi kemandirian dan otonomi yaitu sebesar 3,92 dengan tingkat persentase pelaksanaan sebesar 78,33\% (tinggi/baik).

Berdasarkan perbandingan data skor capaian pelaksanaan pada kedua variabel diatas, maka didapat skor tertinggi pada dimensi tanggung jawab sebesar $83,33 \%$ pada variabel etos kerja ini dibuktikan dengan masih tingginya rasa tanggung jawab karyawan dalam melaksanakan tugas dan kewajibannya sebagai seorang karyawan perusahaan pada tindakan yang dilakukan dan hasil yang didapat setiap karyawan PT Indofarma Global Medika Cabang Palembang yang merupakan perwujudan dari sikap positif yang dimiliki dari para karyawan PT Indofarma Global Medika Cabang Palembang untuk melaksanakan tindakan serta tujuan utama instansi.

Pada hasil pengujian hipotesis data hasil uji statistik t pada tabel 4.21 juga diperoleh nilai sig t variabel etos kerja (X) sebesar $0,000<\alpha=0,05$ dan $t_{\text {hitung }}>$ $t_{\text {tabel }}(4.4160>2.0687)$, menunjukan bahwa etos kerja memiliki pengaruh kinerja karyawan PT Indofarma Global Medika Cabang Palembang. Dan uji koefisien determinasi $\left(\mathrm{R}^{2}\right)$ atau $R$ Square sebesar 0,696 atau 69,6\% nilai tersebut lebih besar dari nilai $\mathrm{R}$ tabel 0,413 . Maka variabel etos kerja $(\mathrm{X})$ dapat dijelaskan atau mempengaruhi variabel kinerja karyawan (Y) PT Indofarma Global Medika Cabang Palembang sedangkan sisanya sebesar 30,4\% berpengaruh dengan faktor 
lain yang tidak dibahas didalam penelitian seperti strategi, promosi, loyalitas karyawan dan faktor-faktor lain-lainnya.

Temuan ini mendukung penelitian yang dilakukan oleh Eka Nurul Bija Rohma pada tahun 2019 yang berjudul "pengaruh etos kerja terhadap kinerja guru di madrasah ibtidaiyah ma'arif nahdlatul ulama pucang sidoarjo", yang menyatakan adanya pengaruh antara variabel $\mathrm{X}$ etos kerja terhadap variabel $\mathrm{Y}$ kinerja karyawan. Dimana hasil uji statistik di peroleh thitung 4,7161 $(\mathrm{p}=0,000)$ dengan nilai signifikansi $(\mathrm{P})<0,01$, berarti terdapat pengaruh etos kerja terhadap kinerja karyawan. Sumbangan dari efektif etos kerja terhadap kinerja karyawan sebesar $68,21 \%$ sedangkan $31,79 \%$ merupakan sumbangan efektif dari faktorfaktor lain, seperti promosi, penjualan, market, dan faktor-faktor lainnya.

Hasil dalam penelitian ini menunjukan bahwa etos kerja memliki pengaruh terhadap kinerja karyawan. Hal ini mengindikasikan bahwa etos kerja yang terdiri dari kerja keras; disiplin; jujur; tanggung jawab; rajin; dan tekun, sebagai variabel bebas (X) dan merupakan faktor yang memiliki hubungan serta pengaruh terhadap variabel terikat (Y) kinerja karyawan Indofarma Global Medika Cabang Palembang, yang meliputi kualitas; kuantitas; aktualitas dan ketepatan waktu; efektivitas; kemandirian dan otonomi. Artinya, etos kerja adalah salah satu faktor yang berpengaruh terhadap kinerja karyawan PT Indofarma Global Medika Cabang Palembang. Jadi semakin tinggi etos kerja yang dimiliki oleh para karyawan, maka kinerja karyawan dari PT Indofarma Global Medika Cabang Palembang juga akan semakin tinggi.

Namun di masa pandemi seperti sekarang banyaknya peraturan pemerintah terkait pembatasan untuk memutus mata rantai covid-19 yang masih menyebar luas di Indonesia bahkan di seluruh dunia sedikit membuat beberapa karyawan sedikit belum bisa beradaptasi dengan beberapa aturan yang harus di taati selama pandemi dan rasa takut yang terus tetap menghantui akan terindikasi virus covid19 karna mesti harus tetap melakukan kunjungan ke apotek-apotek, rumah sakit, dinas Kesehatan, dan laian-lain yang menjadi tujuan pasar perusahaan. Oleh karena itu beberapa karyawan sedikit kurang percaya diri dalam melakukan tugas untuk melakukan kunjungan dan menjalin komunikasi dengan satuan kerja untuk melakukan penawaran produk sehingga hasil yang di dapat kurang maksimal, 
mereka juga mengalami kejenuhan karena banyak kegiatan sekarang yang di batasi untuk mematuhi protokol kesehatan yang telah di terapkan seperti tidak bisanya bertemu langsung dengan satuan kerja untuk melakukan penawaran produk dan juga tidak bisa bertatap muka saat melakukan meeting koordinasi di setiap kesempatannya. Dengan keadaan ini juga yang membuat beberapa karyawan menjadi sedikit kehilangan rasa semangat kerja karena target penjualan yang juga menjadi salah satu tolak ukur kinerja karyawan yang telah di tetapkan tidak tercapai. Hal inilah yang membuat etos kerja karyawan dapat dikatakan cenderung menurun dari dimensi kerja keras, disiplin dan tanggung jawab karyawan cenderung menurun sehingga karyawan tidak bisa maksimal dalam menjalankan tugas membuat kualitas karyawanpun menjadi ikut menurun.

Maka dari itu, kedepannya diperlukan peningkatan dari pelaksanaan etos kerja dengan lebih baik lagi, karena hal tersebut akan memberi kontribusi yang cukup signifikan dalam meningkatkan kinerja bagi karyawan PT Indofarma Global Medika Cabang Palembang.

\section{SIMPULAN DAN SARAN}

\section{Simpulan}

Berdasarkan hasil analisis penelitian dan pembahasan tentang pengaruh etos kerja terhadap kinerja karyawan PT Indofarma Global Medika Cabang Palembang, maka dapat disimpulkan sebagai berikut:

1. Terdapat pengaruh yang signifikan etos kerja terhadap kinerja karyawan PT Indofarma Global Medika Cabang Palembang dibuktikan dengan data yang di dapat pada uji koefisien determinasi $\left(\mathrm{R}^{2}\right)$ atau $R$ Square sebesar 0,696 atau 69,6\% nilai tersebut lebih besar dari nilai $\mathrm{R}$ tabel 0,413. Maka variabel etos kerja (X) dapat dijelaskan atau mempengaruhi variabel kinerja karyawan (Y) PT Indofarma Global Medika Cabang Palembang sedangkan sisanya sebesar $30,4 \%$ berpengaruh dengan faktor lain yang tidak dibahas didalam penelitian seperti strategi, promosi, loyalitas karyawan dan faktor-faktor lain-lainnya, dan pada uji statisti $\mathbf{t}$ variabel etos kerja (X) sebesar $0,000<\alpha=0,05$ dan $t_{\text {hitung }}$ $>t_{\text {tabel }}(4.4160>2.0687)$, maka dapat dinyatakan bahwa $\mathrm{H}_{\mathrm{a}}$ diterima dan $\mathrm{H}_{\mathrm{o}}$ ditolak. 
2. Turunnya etos kerja karyawan PT Indofarma Global Medika Cabang Palembang sehingga kinerja karyawan secara kualitas dan kuantitas menurun akibat dari normal baru pada masa pandemi COVID-19 yang saat ini melanda bukan hanya di Negara Indonesia namun di seluruh penjuru Dunia.

3. Didapat skor tertinggi pada dimensi tanggung jawab yaitu sebesar 83,33\% pada variabel etos kerja ini dibuktikan dengan masih tingginya rasa tanggung jawab karyawan dalam melaksanakan tugas dan kewajibannya sebagai seorang karyawan perusahaan pada tindakan yang dilakukan dan hasil yang didapat..

\section{Saran}

Berdasarkan hasil penelitian, pembahasan dan kesimpulan yang diperoleh, maka saran yang dapat diberkan adalah sebagai berikut ;

1. Bagi Instansi Terkait

2. Sebaiknya perusahaan meningkatkan kualitas karyawannya dengan cara memberi motivasi, memberikan fondasi yang kuat serta membagi cara kepada seluruh karyawan agar dapat membebaskan diri dari belenggu rendah diri agar terbebas dari turunnya rasa percaya diri karyawan dalam melakukan tugas dan tanggung jawabnya agar hasil yang didapat lebih maksimal.

3. Sebaiknya perusahaan membuat atmosfer kerja yang menyenangkan seperti mengadakan agenda liburan rutin untuk para karyawan, memberikan penghargaan pada karyawan yang berprestasi, dan memberikan karir yang pasti kepada karyawannya agar seluruh karyawan terlepas dari rasa jenuh saat bekerja agar kuantitas yang di dapat menjadi lebih maksimal maksimal.

4. Hendaknya atasan dapat terus memberikan coaching clinic, membagi strategistrategi dalam bekerja, dan turun langsung ke lapangan untuk memecahkan isue yang ada dilapangan agar para karyawan tetap semangat dalam bekerja dan dapat meraih target yang sudah di tetapkan oleh perusahaan secara efektif.

\section{DAFTAR PUSTAKA}

Amir, Taufik. 2010. Perilaku Orgnisasi. Jakarta: Kencana, 2017. 
Arikunto, Suharsimi. Prosedur Penelitian Suatu Pendekatan Praktik. Jakarta: Rineka Cipta.

Azizah Nur, Alam Syamsul, Dan Basri Muhammad. 2018. Pengaruh Etos Kerja Terhadap Kinerja Pegawai Pada Dinas Koperasi, Usaha Mikro, Kecil Dan Menengah Provinsi Sulawesi Utara Memiliki Pengaruh. Sulawesi Tenggara: Universitas Halu Oleo.

Bintoro, Dan Daryanto. 2017 Manajemen Penelitian Kinerja Karyawan. Yogyakarta: Penerbit Gava Medika.

Bungin, Burhan. 2014. Metodologi Penelitian Kuantitatif: Kumunikasi, Ekonomi Dan Kebijakan Publik Serta Serta Ilmu-Ilmu Sosial Lainnya. Edisi Kedua, Jakarta: Prenadamedia Group

Busro, Muhammad. 2018.Teori-Teori Manajemen Sumber Daya Manusia. Jakarta: Prenada Media Group.

Colquitt Jason A., Jeffery A. Lepine And Michael J. Wesson. 2009.Organization Behavior. Singapura: Mcgraw-Hill.

Dharma, Surya. 2014. Manajemen Kinerja, Falsafah, Teori Dan Penerapannya. Yogyakarta: Pustaka Pelajar.

Effendi, Usman. 2014. Asas Manajemen. Jakarta: PT Raja Grafindo Persada.

Fahmi, Irham. 2016. Pengantar Ilmu Kepemimpinan. PT Raja Grafindo Persada.

Ginting, Desmon. 2016. Etos Kerja: Panduan Menjadi Karyawan Cerdas. Jakarta: PT Ellex Media Komputindo.

Ghozali, Imam. 2011. Aplikasi Analisis Multivariate Dengan Program Spss. Jakarta: Kencana.

Gilbert Daniel R., James A.F. Stonerj, And Edward Freeman. 2010. Manajemen. $6^{\text {th }}$ Edition. New Delhi: India Pearson.

Handoko, T. Hani. 1994. Manajemen Personalia Dan Sumber Daya Manusia. Yogyakarta: Bpfe.

Hardiansyah Andri, Yanwar Purnamasari Rini. 2015. Pengaruh Etos Kerja Terhadap Kinerja Karyawan PT AE. Jakarta: Universitas Al Azhar Indonesia.

Hasibuan, Malayu Sp. 2004. Manajemen. Edisi Revisi. Jakarta: Pt Bumi Aksara.

Ilias, Yaslis. 2005. Teori Dan Penelitian. Yogyakarta: Liberty.

Kiggudu, Mosses N. 1989. Managing Organization In Development Contried: An Opration And Strategies Approach. West Harford: Kumarian Press Inc. 
Luthfia Salsabila Maulidia, Djaelani Abd. Qodir, Dan Slamet Afi Rachmat. 2019. Pengaruh Etos Kerja, Disiplin Kerja Dan Komitmen Organisasi Terhadap Kinerja Pegawai Kantor Kementrian Agama Kota Baru. Malang: Universitas Islam Malang.

Mangkunegara, A. A. Anwar Prabu. 2000. Manajemen Sumber Daya Perusahaan. Bandung: PT Remaja Rosdakarya.

Moekijad. 1999. Manajemen Sumber Daya Manusia (Manajemen Kepegawaian). Bandung: CV Mandar Maju.

Nawawi, H. Hadari. 2000. Manajemen Sumber Daya Manusia. Cetakan Ketiga. Yogyakarta: Gama Press.

Nazir, Muhammad. 2003. Metode Penelitian. Jakarta: Ghalia Indonesia.

Newstrome, John W. 2008. Organization Behavior. Human Behavior At Work $12^{\text {th }}$ Edition Singapura: Mcgraw-Hill Internatonal Inc.

Noor, Juliansyah. 2013. Penelitian Ilmu Manajemen: Tinjauan Filosofis Dan Praktis. Edisi Pertama. Jakarta: Kencana Prenada Media Group.

Pratana Amelinda, Abadi Ferryal. 2018. Analisis Pengarus Etos Kerja, Hubungan Kerja Dan Pengembangan Karir Terhadap Komitmen Organisasional Berdampak Pada Kinerja Karyawan. Jakarta: Institut Teknologi Dan Bisnis Kalbis.

Robbins, P. Stephen. 2000. Organization Behavior Concepts Controversies Apllication. New Jersey: Prentice-Hall Inc.

Samsudin, Sadili. 2006. Manajemen Sumber Daya Manusia. Bandung: Pustaka Setia.

Sendow. 2007. Pengukuran Kinerja Karyawan. Jakarta: Gunung Agung.

Siagian, Sondang P. 2015. Manajemen Sumber Daya Manusia. Jakarta: PT Bumi Aksara.

Simamora, Hendry. 2004. Manajemen Sumber Daya Manusia. Yogyakarta: Stie.Ykpn.

Sinamo, Jansen H. 2005. Etos Kerja Dalam Bisnis. Jakarta: Institud Darma Mahardika.

Sugiyono. 2014. Metode Penelitian: Kualitatif, Kuantitatif, Dan R\&D. Jakarta: Alfabeta.

Sugiyono. 2014. Metode Penelitian Administrasi. Bandung: Alfabeta.

Sugiyono. 2014. Metode Penelitian Kualitatif, Kuantitatif, R\&D. Bandung: Alfabeta.

Sule Erni Tisnawati, Dan Donni Juni Priansa. 2018. Kepemimpinan Dan Perilaku Organisasi (Membangun Organisasi Unggul Di Era Perubahan). Bandung: PT Refika Aditama. 
Sulistiani Ambar Teguh, Dan Rosidah. 2003. Manajemen Sumber Daya Manusia: Konsep, Teori Dan Pengembangan Dalam Konteks Organisasi Publik. Yogyakarta: Penerbit Graha Ilmu.

Sunarto. 2003. Kiat Dan Strategi Pengembangan Karir Di Perusahaan. Jakarta: Ghalia Indonesia.

Sutrisno, Edi. 2013. Manajemen Sumber Daya Manusia. Jakarta: Kencana Prenada Media Group.

Timbuleng Stela, Sumarauw Jacky S. B.. 2015. Etos Kerja, Disiplin Kerja Dan Komitimen Organisasi Pengaruhnya Terhadap Kinerja Karyawan PT Hasrat Abadi Cabang Manado. Manado: Uniersitas Sam Ratulangi Manado.

Tulus, Moh. Agus. 1994. Manajemen Sumber Daya Manusia. Jakarta: PT Grmedia Pustaka Utama.

Rivai, Veithzal. 2004. Manajemen Sumber Daya Manusia Untuk Perusahaan. Cetakan Pertama. Jakarta: PT Raja Grafindo Persada.

Rohma Bija Eka Nurul. 2019. Pengaruh Etos Kerja Terhadap Kinerja Guru Di Madrasah Ibtidaiyah Ma'arif Nahdlatul Ulama Pucang Sidoarjo. Sidoarjo: Universitas Muhammadiyah Sidoarjo.

Wahyono Sentot Imam, Anna Marina, Siti Maro'ah, Dan Widayat. 2018. Pengantar Bisnis. Edisi Pertama. Jakarta: Pranada Media Group (Divisi Kencana).

Yuliarti. 2019. Pengaruh Etos Kerja, Disiplin Kerja Dan Komitmen Organisasi Terhadap Kinerja Pegawai Pada Dinas Perumahan Dan Penataan Ruang Daerah Kabupaten Morowali. Sulawesi Tengah: Pasca Sarjana Universitas Tadulako.

Zulganef. 2018. Metode Penelitian Bisnis Dan Manajemen. Bandung: PT Refika Aditama. 